\title{
The Effect Of Profitability, Size And Liquidity on Firm Value in Consumer Goods Industry Listed on The Indonesia Stock Exchange (IDX)
}

Candra Kurnia Saputri ${ }^{1}$,

Axel Giovanni ${ }^{*}$,

1,2 Departement of Management, Universitas Tidar, Magelang, Indonesia

\begin{tabular}{|c|c|}
\hline ARTICLE INFO & ABSTRACT \\
\hline $\begin{array}{l}\text { ISSN: 2723-1097 } \\
\text { Keywords: } \\
\text { Firm Value; } \\
\text { Profitability ; Size; } \\
\text { Liquidity. }\end{array}$ & $\begin{array}{l}\text { This research was conducted with the aim of knowing the effect between } \\
\text { profitability, size and liquidity on firm value in consumer goods industry sector } \\
\text { companies listed on the Indonesia Stock Exchange (IDX) from } 2014 \text { to 2018. This } \\
\text { research was conducted because there are still differences in research results and } \\
\text { there is fluctuation in the value of the company in the consumer goods industry } \\
\text { sector companies listed on the Indonesia Stock Exchange. The population used in } \\
\text { this study were companies in the consumer goods industry listed on the IDX in the } \\
2014 \text { - } 2018 \text { period. While the sample used in this study were } 37 \text { companies in the } \\
\text { consumer goods industry sector which were selected using the purposive sampling } \\
\text { method. The data analysis technique used is multiple regression analysis in order } \\
\text { to determine the relationship between variables. The results of this study indicate } \\
\text { that profitability, size and liquidity simultaneously have an influence on firm } \\
\text { value. Partially profitability has a positive and significant effect on firm value, size } \\
\text { has no effect on firm value and liquidity has a negative and significant effect on } \\
\text { firm value. }\end{array}$ \\
\hline
\end{tabular}

\section{Pendahuluan}

Tujuan utama dari keuangan perusahaan adalah memaksimalkan nilai perusahaan yang merepresentasikan kesejahteraan pemegang saham (Brigham \& Houston, 2018b). Nilai Perusahaan merupakan harga yang akan diterima oleh pemilik perusahaan apabila perusahaan dijual, tingginya nilai perusahaan akan berdampak pada semakin meningkatnya pula kemakmuran pemegang saham, begitupun sebaliknya (Husnan \& Pudjiastuti, 2015). Ketika perusahaan telah memutuskan untuk menawarkan sahamnya ke publik, maka nilai perusahaan dapat diartikan sebagai pandangan investor terhadap perusahaan tersebut. Melalui nilai perusahaan, investor juga dapat melihat kinerja perusahaan pada periode yang akan datang, dimana nilai perusahaan dihubungkan dengan harga saham yang nantinya akan berdampak pada presepsi investor terhadap perusahaan (Parta \& Sedana, 2018). Apabila harga saham perusahaan tinggi maka investor akan mendapatkan keuntungan sehingga rasa percaya investor terhadap perusahaan juga akan meningkat (Suwardika \& Mustanda, 2017).

Journal of Business and Management Review Vol. 2 No. 22021 Page 092-106

DOI: $10.47153 /$ jbmr22.902021

*Corresponding Author

Email address: axelgiovanni@untidar.ac.id 
Selain dapat digunakan untuk menilai kinerja perusahaan, nilai perusahaan juga dapat dijadikan sebagai suatu ukuran keberhasilan manajemen perusahaan dalam prospek operasi di masa mendatang sehingga menambah kepercayaan investor terhadap perusahaan bahwa kesejahteraannya mampu terpenuhi (Pratama \& Wiksuana, 2016). Pada dasarnya nilai perusahaan dapat diukur menggunakan beberapa aspek, salah satunya melalui harga pasar saham perusahaan yang merepresentasikan bagaimana investor menilai secara keseluruhan atas ekuitas yang dimiliki perusahaan (Rudangga \& Sudiarta, 2016). Nilai perusahaan yang direpresentasikan melalui harga saham dapat dipengaruhi oleh berbagai faktor antara lain seperti kebijakan dividen, keputusan pendanaan, pertumbuhan perusahaan, keputusan investasi, dan ukuran perusahaan (Prastuti \& Sudiartha, 2016). Sedangkan Arindita \& Sampurno (2015) menyatakan bahwa nilai perusahaan dipengaruhi oleh struktur modal, profitabilitas, kebijakan deviden dan ukuran perusahaan. Hal itu sejalan oleh penelitian yang dilakukan Dewi \& Sudiartha (2017) yang menyatakan bahwa profitabilitas dan ukuran perusahaan memberikan pengaruh positif dan signifikan terhadap nilai perusahaan. Hal yang sama dijelaskan oleh Prastuti \& Sudiartha (2016) yang menjelaskan bahwa struktur modal berpengaruh secara positif dan signifikan terhadap nilai perusahaan.

Kinerja perusahaan yang baik memberikan indikasi kepada investor mengenai prospek yang baik di masa depan (Wijaya, 2017). Salah satu variabel yang dapat mencerminkan kinerja perusahaan adalah profitabilitas. Profitabilitas merupakan gambaran bagaimana kapabilitas perusahaan dalam menghasilkan laba dan mengukur tingkat pengembalian atas investasi yang dilakukan (Sukamulja, 2019). Profitabilitas juga dapat merepresentasikan bagaimana kinerja manajemen dalam menjaga efektifitas kegiatan operasi perusahaan. Profitabilitas yang tinggi menggambarkan bahwa perusahaan dapat menghasilkan keuntungan yang tinggi pula. Semakin tinggi nilai profitabilitas mengindikasikan bahwa semakin tinggi pula efisiensi perusahaan dalam menghasilkan laba (Widyantari \& Yadnya, 2017). Tingginya nilai profitabilitas yang dimiliki perusahaan mencerminkan bahwa perusahaan dalam kondisi yang baik sehingga mampu meningkatkan minat para investor untuk berinvestasi. Semakin tinggi minat para investor untuk berinvestasi maka akan semakin tinggi pula harga saham perusahaan yang pada akhirnya dapat meningkatkan nilai perusahaan. Penelitian yang dilakukan oleh Pratiwi \& Wiksuana (2020) menunjukkan hasil bahwa profitabilitas berpengaruh secara positif dan signifikan terhadap nilai perusahaan. Hasil yang sama ditunjukkan oleh penelitian yang dilakukan oleh Pratama \& Wiksuana (2016), Dewi \& Sudiartha (2017), Dewi \& Candradewi (2018), Astuti \& Yadnya (2019) yang juga menjelaskan bahwa hubugan antara profitabilitas dan nilai perusahaan adalah positif dan signifikan. Hal Berebeda ditunjukkan dari penelitian yang dilakukan Herawati (2011) yang menjelaskan bahwa hubungan antara profitabilitas dan nilai perusahaan adalah negatif dan signifikan. Sedangkan Anzlina \& Rustam (2013) dalam penelitiannya menjelaskan bahwa profitabilitas tidak berpengaruh pada besar kecilnya nilai perusahaan. 
Ukuran perusahaan juga menjadi salah satu faktor yang dapat mempengaruhi tinggi rendahnya nilai suatu perusahaan. Besarnya ukuran perusahaan akan membuat perusahaan semakin mudah memperoleh sumber pendanaan baik dari internal maupun eksternal (Rudangga \& Sudiarta, 2016). Widyantari \& Yadnya, (2017) menjelaskan bahwa ukuran perusahaan merupakan gambaran besar kecilnya sebuah perusahaan yang dapat diperlihatkan melalui aset, jumlah penjualan, rata-rata total penjualan dan total aset rata-rata. Besar kecilnya ukuran perusahaan juga akan berdampak pada kekuatan perusahaan dalam melakukan proses tawar-menawar di dalam kontrak keuangan antar perusahaan (Sintyana \& Artini, 2019). Ukuran perusahaan yang besar dan terus berkembang dapat mencerminkan tingkat keuntungan di masa yang akan datang, dan memberikan kemudahan pembiayaan yang nantinya dapat mempengaruhi nilai perusahaan dan menjadi sinyal yang baik bagi para investor. Semakin besar ukuran suatu perusahaan juga merepresentasikan semakin besarnya pula kemampuan perusahaan dalam menanggung risiko yang dihadapi (Arfiyanti \& Pertiwi, 2020).

Peningkatan ukuran perusahaan juga dapat mempermudah perusahaan untuk mendapatkan pendanaan dipasar modal sehingga perusahaan dapat lebih leluasa memanfaatkan dana tersebut untuk meningkatkan nilai perusahaan (Prastuti \& Sudiartha, 2016). Besarnya ukuran perusahaan juga merepresentasikan bahwa perusahaan mengalami pertumbuhan yang baik sehingga nilai perusahaan akan meningkat. Peningkatan nilai suatu perusahaan dapat ditandai dengan kenaikan total aktiva perusahaan yang lebih besar dari jumlah liabilitas perusahaan. Penelitian yang dilakukan oleh Rudangga \& Sudiarta (2016) menjelaskan bahwa hubungan antara ukuran perusahaan dengan nilai perusahaan adalah positif dan signifikan. Hal yang sama ditunjukkan oleh Pratiwi \& Wiksuana (2020) dalam penelitiannya. Sedangkan Sintyana \& Artini (2019) menyatakan bahwa ukuran perusahaan tidak memiliki pengaruh terhadap nilai perusahaan. Hal yang sama juga dinyatakan oleh penelitian yang dilakukan Astuti \& Yadnya (2019). Namun hasil berbeda dinyatakan oleh Prastuti \& Sudiartha (2016) yang dalam penelitiannya menyatakan bahwa hubungan antara ukuran perusahaan dengan nilai perusahaan adalah negatif dan signifikan.

Selain profitabilitas dan ukuran perusahaan, tingkat likuiditas perusahaan juga mampu mempengaruhi besar kecilnya nilai perusahaan. Likuiditas merupakan gambaran bagaimana kemampuan perusahaan dalam melunasi kewajiban jangka pendeknya atau seberapa cepat perusahaan mengubah aset yang dimilikinya menjadi kas (Sukamulja, 2019) Rasio likuiditas penting bagi suatu perusahaan karena rasio ini dapat menggambarkan risiko kredit jangka pendek dan efisiensi penggunaan aset jangka pendek perusahaan. Tingginya tingkat likuiditas suatu perusahaan menunjukkan bahwa perusahaan mampu memenuhi kewajiban jangka pendeknya dengan baik. Tingkat likuiditas suatu perusahaan perlu dijaga dengan baik karena baiknya tingkat likuiditas suatu perusahaan akan berdampak pada keefektifan perusahaan dalam menghasilkan laba yang nantinya berpengaruh pada nilai perusahaan. Suatu perusahaan dinilai likuid apabila dana lancar yang dimiliki perusahaa lebih besar dari utang lancarnya sehingga perusahaan dapat dinyatakan 
dalam keadaan sehat yang akhirnya mampu meningkatkan kredibilitas perusahaan dimata investor. Penelitian yang dilakukan oleh Cahyani \& Wirawati (2019) mengatakan bahwa hubungan antara likuiditas dengan nilai perusahaan adalah positif signifikan Hal yang sama juga dinyatakan oleh Sukarya \& Baskara (2019), dan Uttari \& Yadnya (2018). Berbeda dengan penelitian yang dilakukan oleh Astuti \& Yadnya (2019) yang menyatakan bahwa hubungan antara likuiditas dan nilai perusahaan adalah negatif signifikan. Hasil yang sama juga ditunjukkan pada penelitian yang dilakukan oleh Permana \& Rahyuda (2018).

Berdasarkan uraian penelitian terdahulu dapat dilihat adanya perbedaan hasil penelitian atau research gap yang mendorong penulis untuk melakukan penelitian mengenai faktor - faktor yang mempengaruhi nilai perusahaan. Dalam penelitian ini faktor - faktor yang dipilih adalah profitabilitas, ukuran perusahaan dan Likuiditas. Dalam memaksimalkan nilai perusahaan, manajemen perusahaan harus memperhatikan berbagai faktor yang dapat mempengaruhi nilai perusahaan seperti profitabilitas, ukuran perusahaan dan Likuiditas. Berbeda dengan penelitian yang telah ada, penelitian ini secara lebih lanjut menggabungkan faktor kinerja perusahaan yang direpresentasikan melalui variabel profitabilitas dan likuiditas dan, karateristik perusahaan yang dicerminkan melalui ukuran perusahaan

\section{Kajian Teori}

\section{Signaling Theory}

Signaling theory menjelaskan bahwa tidak semua stakeholder atau pihak - pihak yang memiliki kepentingan pada perusahaan seperti masyarakat, pemerintah dan investor memiliki informasi yang sama mengenai risiko, prospek dan kondisi perusahaan. Pengelola atau manajemen perusahaan biasanya memiliki informasi yang lebih baik dibandingkan dengan stateholder lain sehingga perilaku manajer dianggap sebagai sinyal oleh stakeholder lain terutama investor (Hanafi, 2004). Hal tersebut sesuai dengan Brigham \& Houston (2018) yang menyatakan bahwa signaling theory merupakan tindakan yang dilakukan oleh manajemen perusahaan yang memberikan petunjuk bagi iinvestor mengenai bagaimana manajer melihat prospek perusahaan dimasa yang akan datang. Teori sinyal ini juga menjelaskan bahwa laporan keuangan dan laporan tahunan yang diterbitkan secara sukarela oleh perusahaan merupakan informasi yang dapat digunakan sebagai sinyal oleh investor mengenai bagaimana kinerja perusahaan dan apa saja yang telah dicapai perusahaan. Pengungkapan informasi tersebut bertujuan untuk menarik minat investor utuk berinvestasi, meningkatkan reputasi perusahaan dan memaksimalkan nilai perusahaan.

\section{Nilai Perusahaan}

Nilai perusahaan merupakan nilai sekarang dari arus pendapatan atau kas yang diharapkan diterima pada masa yang akan datang (Sudana, 2011). Menurut Thomas, (2011) nilai perusahaan merupakan harga yang akan diterima oleh pemilik 
perusahaan apabila suatu perusahaan akan dijual. Husnan \& Pudjiastuti (2015) menyatakan bahwa semakin tinggi nilai perusahaan, semakin besar kemakmuran yang akan diterima oleh pemilik perusahaan. Pandangan investor terhadap perusahaan akan dilihat dari nilai perusahaan, karena nilai perusahaan mencerminkan kinerja perusahaan (Dewi \& Candradewi, 2018). Hal itu sejalan dengan penelitian yang dilakukan Yunita \& Artini, (2019) yang menyatakan bahwa nilai perusahaan adalah indikator yang penting dalam menilai kinerja suatu perusahaan, besar kecilnya nilai perusahaan dapat mempengaruhi investor dalam melakukan investasinya. Sedangkan Noviani et al. (2019) menjelaskan bahwa nilai perusahaan dapat tercermin dari harga saham, semakin tinggi harga saham maka semakin tinggi tingkat pengembalian investor dan semakin tinggi nilai perusahaan tersebut.

\section{Profitabilitaa dan Nilai Perusahaan}

Profitabilitas merupakan kemampuan perusahaan dalam menghasilkan laba dimasa yang akan datang dan mencerminkan bgaimana kinerja manajemen dalam menjaga efektifitas kegiatan operasi perusahaan (Sukamulja, 2019). Profitabilitas yang tinggi akan memacu perusahaan untuk tumbuh dan berkembang begitu pula sebaliknya, peningkatan profitabilitas berpengaruh positif terhadap kinerja keuangan perusahaan dalam mencapai tujuan memaksimalkan nilai perusahaan yang akan direspon secara positif oleh investor, sehingga permintaan saham meningkat dan dapat menaikkan harga saham (Iswajuni et al., 2018). Sedangkan Hapsoro \& Falih (2020) menjelaskan bahwa profitabilitas merupakan daya tarik tersendiri bagi pemegang saham karena merupakan hasil yang diperoleh melalui upaya pengelolaan atas dana yang diinvestasikan oleh pemegang saham, serta mencerminkan laba yang menjadi hak pemegang saham. Kinerja suatu perusahaan dapat dinilai dari kemampuan perusahaan dalam menghasilkan laba, karena pada perusahaan profitabilitas dijadikan sebagai penilaian keefektifitasan pengelolaannya. Profitabilitas pada perusahaan dapat dinilai dengan bermacam cara tergantung pada laba dari aktiva atau modal yang diperbandingkan satu dengan lainnya. Profitabilitas merupakan indikator kinerja manajemen yang ditunjukkan melalui perolehan laba selama mengelola kekayaan perusahaan. Semakin besar jumlah profitabilitas perusahaan yang tercatat pada laporan keuangan dapat diartikan bahwa kinerja perusahaan tersebut baik, maka peluang perusahaan pada masa yang akan datang semakin baik (Noviani et al., 2019).

Hasil penelitian yang dilakukan oleh Iswajuni et al. (2018) menjelaskan bahwa hubungan antara profitabilitas dengan nilai perusahaan adalahpositif dan signifikan. Semakin meningkatnya profitabilitas suatu perusahaan maka akan meningkatkan pula nilai perusahaannya karena dengan meningkatnya profitabilitas menunjukkan bahwa kinerja perusahaan meningkat dan dapat diperkirakan bahwa prospek kedepannya perusahaan baik sehingga mampu menarik investor dan meningkatkan harga saham perusahaan yang mana akan mencerminkan meningkatnya pula nilai perusahaan. Hal tersebut selaras dengan penelitian yang dilakukan oleh Suwardika \& 
Mustanda (2017), Dewi \& Candradewi (2018) dan Pratiwi \& Wiksuana (2020). Berdasarkan penjelasan diatas maka penulis mengajukan hipotesis mengenai pengaruh profitabilitas terhadap nilai perusahaan adalah sebagai berikut :

\section{H1 : profitabilitas perbengaruh positif terhadap nilai perusahaan}

\section{Ukuran Perusahaan dan Nilai Perusahaan}

Ukuran perusahaan dapat dicerminkan melalui total aset atau total penjualan bersih perusahaan, semakin besar total aset dan penjualan, semakin besar ukuran sebuah perusahaan (Iswajuni et al., 2018. Ukuran perusahaan menjadi salah satu faktor yang dipertimbangkan investor untuk menginvestasikan dananya karena perusahaan yang berukuran besar cenderung memberikan informasi yang detail untuk memenuhi kebutuhan informasi penggunanya, seperti investor, manajemen, pemerintah, dan pengguna informasi lainnya (Hapsoro \& Falih, 2020). Ukuran perusahaan dapat memberi gambaran kemampuan finansial perusahaan dalam suatu periode tertentu (Cahyani \& Wirawati, 2019). Besar kecilnya ukuran perusahaan juga akan mempengaruhi kemampuan dalam menanggung risiko yang mungkin timbul dari berbagai situasi yang dihadapi perusahaan (Rajagukguk et al., 2019). Ukuran perusahaan dibagi menjadi tiga kategori, yaitu perusahaan besar, menengah dan kecil. Penentuan ukuran perusahaan didasarkan pada total aset perusahaan. Dengan demikian, ukuran perusahaan merupakan ukuran atau jumlah aset yang dimiliki oleh perusahaan (Iswajuni et al., 2018)

Semakin besar ukuran dari suatu perusahaan maka akan semakin kecil risiko yang dihadapi perusahaan apabila dibandingkan dengan perusahaan yang berukuran kecil, karena perusahaan yang berukuran besar dianggap memiliki kontrol yang lebih baik terhadap kondisi pasar sehingga mampu menghadapi persaingan yang ketat (Hapsoro \& Falih, 2020). Semakin besar ukuran perusahaan juga turut menentukan tingkat kepercayaan investor, karena semakin besar sebuah perusahaan, akan semakin banyak masyarakat yang mengenal perusahaan yang berarti semakin mudah pula untuk memperoleh informasi yang dapat meningkatkan nilai perusahaan (Rajagukguk et al., 2019). Semakin banyak investor yang percaya terhadap sebuah perusahaan, maka semakin banyak modal yang didapatkan oleh perusahaan sehingga akan mempengaruhi harga saham perusahaan dan akan meningkatkan nilai perusahaan. Berdasarkan penjelasan diatas maka penulis mengajukan hipotesis mengenai pengaruh ukuran perusahaan terhadap nilai perusahaan adalah sebagai berikut :

\section{H2 : ukuran perusahaan perbengaruh positif terhadap nilai perusahaan}

\section{Likuiditas dan Nilai Perusahaan}

Likuiditas dapat didefinisikan sebagai kemampuan perusahaan dalam melunasi kewajiban jangka pendeknya seperti pembayaran gaji, biaya operasional, utang jangka pendek dan kewajiban lain yang membutuhkan pembayaran segera 
menggunkan dana yang diiliki perusahaan. Likuiditas suatu perusahaan dapat dilihat dari nilai current ratio $(\mathrm{CR})$ dan quick ratio $(\mathrm{QR})$. Tingginya nilai current ratio $(\mathrm{CR})$ dan quick ratio $(\mathrm{QR})$ menunjukkan bahwa tingkat likuidasi perusahaan baik sehingga dapat meningkatkan nilai perusahaan di mata investor serta memberikan persepsi yang positif terhadap kondisi perusahaan. Sedangkan Sukamulja (2019) menyatakan bahwa likuiditas dapat menunjukkan seberapa cepat perusahaan dapat megubah aset yang dimiliki menjadi kas.

Sukarya \& Bagaskara (2019) dalam penelitiannya menyatakan bahwa tingkat likuiditas suatu perusahaan akan mempengaruhi bagaimana keputusan investor dalam berinvestasi pada suatu perusahaan. Tingginya tingkat likuiditas suatu perusahaan menunjukkan bahwa perusahaan dalam kondisi baik dan mampu memenuhi kewajiban lancarnya. Hal itu dapat menjadi salah satu pertimbangan dan hal yang menarik minat para investor sehingga investor tertarik pada perusahaan untuk melakukan investas. Tingginya minat investor untuk berinvestasi pada suatu perusahaan berdampak pada meningkatnya harga saham dan nilai perusahaan (Cahyani \& Wirawati, 2019). Berdasarkan uraian diatas maka penulis mengajukan hipotesis mengenai pengaruh likuiditas terhadap nilai perusahaan adalah sebagai berikut :

\section{H3 : likuiditas berpengaruh positif terhadap nilai perusahaan}

\section{Metode Penelitian}

\section{Desain Penelitian}

Penelitian ini menggunakan desain penelitian Correlation Research yaitu penelitian yang dialakukan untuk melihat bagaimana hubungan antara dua variable atau lebih. Dimana Variabel dalam penelitian ini ada profitabilitas $\left(\mathrm{X}_{1}\right)$, Ukuran Perusahaan $\left(X_{2}\right)$, Likuiditas $\left(X_{3}\right)$, dan Nilai Perusahaan $\left(Y_{1}\right)$. Peneitian ini menggunakan pendekatan kuantitatif.

\section{Populasi dan Sampel}

Populasi yang digunakan dalam artikel ini adalah seluruh perusahaan pada industri sektor barang konsumsi yang terdafar pada Bursa Efek Indonesia (BEI) sebanyak 61 perusahaan. Dimana sampel dalam penelitian ini ditentukan dengan metode purposive sampling untuk memperoleh sampel yang sesuai dengan karateristik yang telah ditentukan oleh penulis. Adapun karateristik sampel yang ditentukan adalah sebagai berikut :

1. Perusahaan di industri sektor barang konsumsi yang terdafar di Bursa Efek Indonesia pada periode 2014 hingga periode 2018

2. Perusahaan non-keuangan yang secara konsisten mempublikasikan laporan tahunan maupun laporan keuangan periode 2014-2018 secara berturut-turut baik di situs resmi milik perusahaan dan situs resmi milik Bursa Efek Indonesia. 
3. Memiliki dan mempublikasikan data yang lengkap terkait dengan variabel yang digunakan dalam penelitian ini yaitu nilai perusahaan, profitabilitas, ukuran perusahaan dan likuiditas.

Berdasarkan kriteria diatas, diperoleh sebanyak 37 perusahaan pada sektor barang konsumsi di BEI periode 2014 - 2018 yang memenuhi kriteria penelitian dengan estimasi sampel penelitian sebagai berikut :

\section{Tabel 1. Estimasi Sampel Penelitian}

\begin{tabular}{clc}
\hline No & \multicolumn{1}{c}{ Estimasi Sampel Penelitian } & Jumlah \\
\hline 1. & $\begin{array}{l}\text { Perusahaan yang tercantum pada sektor barang konsumsi di BEI } \\
\text { Perusahaan pada sektor barang konsumsi yang terdafar di BEI }\end{array}$ & \\
2. & (20) \\
& $\begin{array}{l}\text { Petelah periode 2014 } \\
\text { mempahaan yang tidak secara konsisten memiliki dan }\end{array}$ \\
2018 & \\
4. Perusahaan yang memenuhi kriteria sampel penelitian & 37 \\
\hline
\end{tabular}

Sumber : $\underline{w w w . i d x . c o . i d}$ dan data diolah penulis dengan Microsoft Excel dan SPSS

\section{Teknik Pengumpulan dan Analisis Data}

Data yang digunakan dalam penelitian ini adalah data sekunder. Data sekunder merupakan data yang diperoleh dari informasi yang dikumpulkan dari sumber yang sudah ada (Sekaran \& Bougie, 2017). Dimana dalam penelitian ini data diperoleh dengan metode dokumentasi dari Bursa Efek Indonesia (BEI) dengan mengakses www.idx.co.id. Pengumpulan data dalam artikel ini dilakukan dengan metode studi pustaka yaitu dengan membaca sumber - sumber yang relevan dengan penelitian seperti buku dan jurnal untuk memperoleh landasan teori.

Dalam penelitian ini data yang telah diperoleh kemuadian dianalisis menggunakan teknik analisis regresi berganda dengan tujuan untuk mengetahui hubungan antar variabel. Dimana variabel dalam penelitian ini terdiri dari variabel dependen yiatu nilai perusahaan dan variabel independen yang terdiri dari profitabilitas, pertumbuhan perusahaan dan likuiditas. Nilai perusahaan dalam penelitian ini diukur menggunakan Price Book Value (PVB). Price Book Value merupakan salah satu rasio yang dapat digunakan untuk mengukur nilai perusahaan dengan membandingkan antara harga per lembar saham dengan nilai buku perusahaan. Berikut merupakan rumus dalam menghitung Price Book Value suatu perusahaan :

$$
\text { Price Book Value }=\frac{\text { Harga Saham }}{\text { Nilai Buku }}
$$


Variabel profitabilitas dalam penelitian ini diukur menggunakan Return on Equiy (ROE). Dalam penelitian ini pengukuran profitabilitas dilakukan dengan ROE karena ROE merupakan rasio pengukuran kemampuan perusahaan untuk menghasilkan laba dari ekuitas yang dimiliki perusahaan. Selain itu ROE juga dapat mencerminkan tingkat pengembalian dari saham yang dimiliki perusahaan untuk pemegang sahamnya sehingga lebih besar pengaruhnya pada nilai perusahaan bila dibandingkan dengan ROA yang mengukur tingkat pengembalian atas investasi perusahaan yg dalam hal ini dinilai melalui aset perusahaan (Sukamulja, 2019). ROE dapat diukur menggunakan rumus berikut :

$$
\text { Returon on Equity }=\frac{\text { Laba Bersih }}{\text { Total Ekuitas }}
$$

Variabel ukuran perusahaan dalam penelitian ini diukur menggunakan Logaritma Natural Total Asset yang dimiliki perusahaan. Berikut merupakan rumus perhitungan Ln Total Asset :

$$
\text { Ukuran Perusahaan }=\operatorname{Ln}(\text { Total Asset })
$$

Dan likuiditas dalam penelitian ini diukur menggunakan current ratio. Current ratio adalah perbandingan antara aset lancar perusahaan terhadap liabilitas jangka pendeknya. Berikut merupakan rumus perhitungan Current Ratio dalam penelitian ini :

$$
\text { Current Ratio }=\frac{\text { Aset Lancar }}{\text { Liabilitas Lancar }}
$$

\section{Hasil dan Pembahasan}

\section{Hasil}

Dalam penelitian ini analisis data dilakukan dengan analisis regresi berganda menggunakan SPSS 21. Hasil dari uji asumsi klasik dalam model regresi memperlihatkan adanya masalah autokorelasi dan heteroskedastisitas. Permasalahan autokorelasi dan heteroskedastisitas dalam model regresi akan berdampak pada inferensi secara statistik dalam penelitian menjadi tidak valid (Gujarati \& Porter, 2009). Untuk mengatasi permasalahan tersebut penelitian ini menggunakan prosedur robust standard error. Robust standard error adalah prosedur valid dalam analisis regresi yang bertujuan untuk mengatasi permasalahan autokorelasi dan heteroskedastisitas dengan mengoreksi atau melakukan suatu adjustment terhadap standard error model regresi sehingga penarikan kesimpulan secara statistik tetap dapat dilakukan (Gujarati \& Porter, 2009). Hasil akhir model regresi dalam penelitian ini setelah dilakukan robust test disajikan dalam tabel berikut ini : 
Tabel 2. Model Regresi Penelitian

\begin{tabular}{ccccc}
\hline Variabel & Koefisien Regresi & Robust Standard Error & $\mathrm{t}$ & $\mathrm{P}$ \\
\hline (contstant) & -6.5649 & 7.8560 & -.83357 & .4045 \\
\hline ROE & .2020 & .0793 & 2.5483 & .0117 \\
\hline Size & .7262 & .5660 & 1.2831 & .2011 \\
\hline Current Ratio & -.0076 & .0027 & -2.7994 & .0057 \\
\hline
\end{tabular}

Sumber : Hasil Pengolahan Data SPSS 21

\section{Koefisien Determinasi}

Koefisisen determinasi memperlihatkan besarnya pengaruh variabel independen dalam penelitian yaitu profitabilitas, ukuran perusahaan dan likuiditas terhadap variabel dependen dalam penelitian yaitu nilai perusahaan pada perusahaan sektor industri barang konsumsi yang terdaftar di BEI pada periode 2014 - 2018 . Berikut merupakan tabel koefisien determinasi dalam penelitian ini :

Tabel 3. Koefisien Determinasi

\begin{tabular}{rrrrr} 
Model & R & R Square & Adjusted R Square & Std. Error of the Estimate \\
\hline 1 & .6539 & .4276 & .4161 & 8.8966 \\
\hline
\end{tabular}

Sumber : Hasil Pengolahan Data SPSS 21

Dari tabel diatas dapat kita lihat nilai koefisien determinasi yang ditunjukan oleh nilai Adjusted R Square menunjukkan nilai sebesar 0,4276 atau 42,76\%. Nilai koefisien determinasi tersebut menjelaskan bahwa 42,76 persen variasi nilai perusahaan dapat dijelaskan melalui profitabilitas perusahaan, ukuran perusahaan dan tingkat likuiditas perusahaan. Sedangkan pengaruh faktor lain diluar variabel dalam penelitian ini adalah sebesar $(100 \%-42,76 \%) 57,24 \%$,

\section{Uji F}

Hasil dari uji F diperoleh kesimpulan bahwa profitabilitas, ukuran perusahaan dan likuiditas perusahaan terbukti secara bersama - sama atau simultan berpengaruh terhadap variabel nilai perusahaan. Hal itu dibuktikan dengan nilai P sebesar 0,0000 yang lebih kecil dari nilai signifikansi yang digunakan dalam penelitian yaitu $5 \%$. Selaian itu hasil Uji Statistik F yang ditunjukkan pada tabel 8 membuktikan bahwa model regresi peneltian ini terspesifikasi secara tepat. Hasil uji F dalam penelitian ini disajikan dalam tabel berikut ini :

Tabel 4. Hasil Uji F

\begin{tabular}{ccc}
\hline F & $\mathbf{P}$ & Hasil \\
\hline 9.9570 & .0000 & Signifikan \\
\hline \multicolumn{2}{c}{ Sumber : Hasil Pengolahan Data SPSS 21}
\end{tabular}

\section{Uji t}


Hasil uji $\mathrm{t}$ dalam penelitian ini menyatakan bahwa variabel profitabilitas dan likuiditas perusahaan berpengaruh secara parsial terhadap nilai perusahaan dengan nilai P yang diperoleh kurang dari nilai signifikansi (5\%) yaitu sebesar 0,0117 untuk variabel profitabilitas dan 0, 0057 untuk variabel likuiditas. Sedangkan variabel ukuran perusahaan tidak berpengaruh secara parsial terhadap nilai perusahaan dengan nilai P yang diperoleh sebesar 0, 2011 lebih besar dari pada nilai signifikansi (5\%) yang digunakan dalam penelitian ini. Hasil Uji t model regresi penelitian dirangkum melalui tabel berikut :

Tabel 5. Hasil Uji t

\begin{tabular}{cccc}
\hline Variabel & Nilai thitung & $\mathbf{P}$ & Hasil \\
\hline ROE & 2.5483 & .0117 & Signifikan \\
Size & 1.2831 & .2011 & Tidak Signifikan \\
Current Ratio & -2.7994 & .0057 & Signifikan \\
\hline
\end{tabular}

Sumber : Hasil Pengolahan Data SPSS 21

\section{Pembahasan}

\section{Pengaruh Profitabilitas terhadap nilai perusahaan}

Hasil uji t dalam penelitian ini menunjukkan bahwa profitabilitas berpengaruh secara parsial terhadap nilai perusahaan dengan nilai $\mathrm{P}$ yang diperoleh pada tabel 5 yaitu sebesar 0,0117 lebih kecil dari nilai signifikansi (5\%) yang digunakan dalam penelitian ini. Pada tabel 5 juga menunjukkan bahwa $t_{\text {hitung }}$ yang diperoleh variabel profitabilitas sebesar 2,5483 yang menunjukkan bahwa arah koefisien dari variabel profitabilitas adalah positif. Dari hasil tersebut dapat disimpulkan bahwa profitabilitas berpengaruh positif signifikan terhadap nilai perusahaan. Hal itu juga mengartikan bahwa hipotesis pertama dalam penelitian ini didukung dan sejalan dengan penelitian yang dilakukan oleh Arindita \& Sampurno (2015) menjelaskan bahwa profitabilitas berpengaruh positif signifikan terhadap nilai perusahaan. Semakin meningkatnya profitabilitas suatu perusahaan maka akan meningkatkan pula nilai perusahaannya karena dengan meningkatnya profitabilitas menunjukkan bahwa kinerja perusahaan meningkat dan dapat diperkirakan bahwa prospek kedepannya perusahaan baik sehingga mampu menarik investor dan meningkatkan harga saham perusahaan yang mana akan mencerminkan meningkatnya pula nilai perusahaan.

\section{Pengaruh Ukuran Perusahaan terhadap nilai perusahaan}

Hasil uji $\mathrm{t}$ dalam penelitian ini menunjukkan bahwa ukuran perusahaan tidak berpengaruh secara parsial terhadap nilai perusahaan dengan nilai $\mathrm{P}$ yang diperoleh pada tabel 5 yaitu sebesar 0,2011 lebih besar dari nilai signifikansi (5\%) yang digunakan dalam penelitian ini. Pada tabel 4 juga menunjukkan bahwa thitung yang diperoleh variabel pertumbuhan perusahaan sebesar 1.2831 yang menunjukkan 
bahwa arah koefisien dari variabel ukuran perusahaan adalah positif. Dari hasil tersebut dapat disimpulkan bahwa ukuran perusahaan tidak berpengaruh terhadap nilai perusahaan. Hal itu juga mengartikan bahwa hipotesis kedua dalam penelitian ini tidak didukung. Hal tersebut selaras dengan penelitian yang dilakukan Sintyana \& Artini (2019) yang menyatakan bahwa ukuran perusahaan tidak berpengaruh terhadap nilai perusahaan. Tidak adanya pengaruh tersebut menjelaskan bahwa apabila ukuran perusahaan meningkat maka nilai perusahaan belum tentu mengalami peningkatan juga.

\section{Pengaruh Likuiditas terhadap nilai perusahaan}

Hasil uji $\mathrm{t}$ dalam penelitian ini menunjukkan bahwa Likuiditas, yang pada penelitian ini diproksikan dengan Current Ratio, berpengaruh secara parsial terhadap nilai perusahaan dengan nilai $\mathrm{P}$ yang diperoleh yaitu sebesar 0,0057 lebih kecil dari nilai signifikansi (5\%) yang digunakan dalam penelitian ini. Pada tabel 5 juga

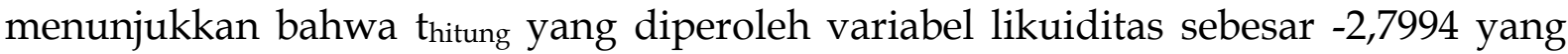
menunjukkan bahwa arah koefisien dari variabel likuiditas adalah negatif. Dari hasil tersebut dapat disimpulkan bahwa likuiditas berpengaruh negatif signifikan terhadap nilai perusahaan. Hal itu juga mengartikan bahwa hipotesis ketiga dalam penelitian ini tidak didukung. Hasil tersebut sejalan dengan penelitian yang dilakukan oleh Permana \& Rahyuda (2018) yang menyatakan bahwa likuiditas berpengaruh negatif signifikan terhadap nilai perusahaan. Hal itu berarti bahwa tingkat likuiditas yang terlalu tinggi akan berdampak pada besar kecilnya return yang diterima oleh pemegang saham. Tingkat likuiditas perusahaan yang terlalu tinggi juga menunjukkan banyaknya jumlah kas perusahaan yang tidak dikelola dengan optimal sehingga dapat menghambat kemampuan produktivitas perusahaan dalam menghasilkan laba. Laba yang kecil mengindikasikan tingkat pengembalian yang kecil pula sehingga investor akan mempertimbangkan kembali keputusannya dalam melakukan investasi yang pada akirnya berdampak pada nilai perusahaan.

\section{KESIMPULAN}

Kesimpulan pada penelitian ini adalah variabel profitabilitas memiliki pengaruh yang positif dan signifikan terhadap nilai perusahaan di perusahaan sektor industri barang konsumsi yang terdaftar di Bursa Efek Indonesia tahun 2014 - 2018. Pengaruh positif dan signifikan tersebut menunjukkan semakin meningkatnya profitabilitas suatu perusahaan maka akan meningkatkan pula nilai perusahaannya. Variabel ukuran perusahaan tidak memiliki pengaruh terhadap nilai perusahaan di perusahaan sektor industri barang konsumsi yang terdaftar di Bursa Efek Indonesia tahun 2014 - 2018. Hasil penelitian tersebut menunjukkan bahwa meningkat atau menurunnya ukuran perusahaan tidak berpengaruh terhadap nilai perusahaan. Dan 
variabel likuiditas memiliki pengaruh yang negatif dan signifikan terhadap nilai perusahaan di perusahaan sektor industri barang konsumsi yang terdaftar di Bursa Efek Indonesia tahun 2014 - 2018. Pengaruh negatif dan signifikan tersebut menunjukkan bahwa tingginya likuiditas perusahaan tidak selalu dapat meningkatkan nilai perusahaan.

Untuk penelitian selanjutnya penulis memberikan saran agar dapat meneliti faktor atau variabel lain agar didapatkan hasil yang maksimal mengenai apa saja faktor yang dapat mempengaruhi nilai suatu perusahaan. Bagi perusahaan, sebaiknya memperhatikan dan menganalisis faktor - faktor yang mempengaruhi besar kecilnya nilai perusahaan sehingga dapat mengetahui bagaimana cara mencapai nilai perusahaan yang diinginkan. Dan bagi investor, sebaiknya melakukan analisis terlebih dahulu terutama mengenai faktor - faktor yang dapat mempengaruhi nilai perusahaan sebelum melakukan pengambilan keputusan investasi.

\section{DAFTAR PUSTAKA}

Anzlina, C. W., \& Rustam. (2013). Pengaruh Tingkat Likuiditas, Solvabilitas, Aktivitas, dan Profitabilitas Terhadap Nilai Perusahaan Real Estate dan Property di BEI Tahun 2006-2008. Jurnal Ekonom, 16(2), 67-75.

Arfiyanti, D., \& Pertiwi, I. F. P. (2020). Determinant of Indonesian Islamic Banks Liquidity Risk. Journal of Business Management Review, 1(4), 281-294. https:/ / doi.org/10.47153/jbmr14.332020

Arindita, G., \& Sampurno, R. D. (2015). Analisis Pengaruh Struktur Modal, Profitabilitas, Kebijakan Dividen, Dan Size Terhadap Nilai Perusahaan (Studi Kasus pada perusahaan Wholesale dan Retail yang terdaftar di BEI tahun 20082012). Diponegoro Journal of Management.

Astuti, N. K. B., \& Yadnya, I. P. (2019). Pengaruh Profitabilitas, Likuiditas, Dan Ukuran Perusahaan Terhadap Nilai Perusahaan Melalui Kebijakan Dividen. Jurnal Manajemen Udayana, 8(5), 3275-3302.

Brigham, E. F., \& Houston, J. F. (2018a). Dasar-Dasar Manajemen Keuangan (14th ed.). Jakarta: Salemba Empat.

Brigham, \& Houston. (2018b). DASAR DASAR MANAJEMEN KEUANGAN (14th ed.). Salemba Empat.

Cahyani, G. A. P., \& Wirawati, N. G. P. (2019). Pengaruh Likuiditas, Kebijakan Dividen, Profitabilitas, dan Ukuran Perusahaan pada Nilai Perusahaan. E-Jurnal Akuntansi, 27, 1263. https:// doi.org/10.24843/eja.2019.v27.i02.p16

Dewi, D. A. I. Y. M., \& Sudiartha, G. M. (2017). Pengaruh Profitabilitas, Ukuran Perusahaan, Dan Pertumbuhan Aset Terhadap Struktur Modal Dan Nilai Perusahaan. Jurnal Manajemen Udayana, 6(4), 2222-2252.

Dewi, M. A. P., \& Candradewi, M. R. (2018). Pengaruh Pertumbuhan Perusahaan Dan Profitabilitas Terhadap Struktur Modal Dan Nilai Perusahaan. Jurnal Manajemen Udayana, 7(8), 4385-4416.

Gujarati, D. N., \& Porter, D. C. (2009). Basic Econometris (5th ed).

Hanafi, M. M. (2004). Manajemen Keuangan. BPFR-Yogyakarta. 
Hapsoro, D., \& Falih, Z. N. (2020). The Effect of Firm Size , Profitability , and Liquidity on The Firm Value Moderated by Carbon Emission Disclosure. Journal of Accounting and Investment, 21(2), 240-257. https:/ / doi.org/10.18196/jai.2102147

Herawati, T. (2011). Pengaruh kebijakan dividen, kebijakan hutang dan profitabilitas terhadap nilai perusahaan. 1-18.

Husnan, S., \& Pudjiastuti, E. (2015). Dasar - Dasar Manajemen Keuangan. Yogyakarta. UPP STIM YKPN.

Iswajuni, I., Manasikana, A., \& Soetedjo, S. (2018). The effect of enterprise risk management (ERM) on firm value in manufacturing companies listed on Indonesian Stock Exchange year 2010-2013. Asian Journal of Accounting Research, 3(2), 224-235. https:// doi.org/10.1108/ajar-06-2018-0006

Noviani, A. V., Atahau, A. D. R., \& Robiyanto, R. (2019). Struktur modal, profitabilitas, dan nilai perusahaan: Efek moderasi Good Corporate Governance. Jurnal Ekonomi Dan Bisnis, 22(2), 391-415. https:/ / doi.org/10.24914/jeb.v22i2.2601

Parta, K. A. C. P. P., \& Sedana, I. B. P. (2018). Peran Struktur Modal Dalam Memediasi Pengaruh Pertumbuhan Perusahaan Terhadap Nilai Perusahaan Pada Perusahaan Properti Di Bei. Jurnal Manajemen Udayana, 7(5), 2680-2709.

Permana, A. A. N. B. A., \& Rahyuda, H. (2018). Pengaruh Profitabilitas, Solvabilitas,Likuiditas, Dan Inflasi Terhadap Nilai Perusahaan. E-Jurnal Manajemen Universitas Udayana, 8(3), 1577-1607. https://doi.org/10.24843/ejmunud.2019.v08.i03.p15

Prastuti, N. K. R., \& Sudiartha, I. G. M. (2016). Pengaruh struktur modal, kebijakan dividen, dan ukuran perusahaan terhadap nilai perusahaan pada perusahaan manufaktur. Jurnal Manajemen Udayana, 5(3), 1572-1598.

Pratama, I. G. B. A., \& Wiksuana, I. G. B. (2016). Pengaruh Ukuran Perusahaan Dan Leverage Terhadap Nilai Perusahaan Dengan Profitabilitas Sebagai Variabel Mediasi. Jurnal Manajemen Udayana, 5(2), 1338-1367.

Pratiwi, I. D. A. I., \& Wiksuana, I. G. B. (2020). Pengaruh Struktur Modal, Ukuran Perusahaan, Dan Profitabilitas Terhadap Nilai Perusahaan Property Di Bursa Efek. Jurnal Manajemen Udayana, 9(6), 2394-2413.

Rajagukguk, L., Ariesta, V., \& Pakpahan, Y. (2019). Analisis Pengaruh Profitabilitas, Ukuran Perusahaan, Keputusan Investasi, dan Kebijakan Utang Terhadap Nilai Perusahaan. Jurnal Inspirasi Bisnis Dan Manajemen, 3(1), 77. https://doi.org/10.33603/jibm.v3i1.2079

Rudangga, I. G. N. G., \& Sudiarta, G. M. (2016). Pengaruh Ukuran Perusahaan, Leverage, Dan Profitabilitas Terhadap Nilai Perusahaan. Jurnal Manajemen Udayana, 5(7), 4394-4422.

Sekaran, U., \& Bougie, R. (2017). Metode Penelitian untuk Bisnis. Jakarta: Salemba Empat.

Sintyana, I. P. H., \& Artini, L. G. S. (2019). Pengaruh Profitabilitas, Struktur Modal, Ukuran Perusahaan Dan Kebijakan Dividen Terhadap Nilai Perusahaan. Jurnal Manajemen Udayana, 8(2), 7717-7745.

Sudana, I. M. (2011). Manajemen Keuangan PerusahaanTeori dan Praktik. ERLANGGA. Sukamulja, S. (2019). Analisis Laporan Keuangan Sebagai Dasar Pengambilan Keputusan 
Investasi (F. M (ed.)). PENERBIT ANDI.

Sukarya, I. P., \& Bagaskara, I. G. K. (2019). Pengaruh Profitabilitas, Leverage, Dan Likuiditas Terhadap Nilai Perusahaan Sub Sektor Food And Beverages. E-Jurnal Manajemen, 8(1), 7399-7428.

Suwardika, I. N. A., \& Mustanda, I. K. (2017). Pengaruh Leverage, Ukuran Perusahaan, Pertumbuhan Perusahaan, Dan Profitabilitas Terhadap Nilai Perusahaan Pada Perusahaan Properti. Jurnal Manajemen Udayana, 6(3), 1248-1277.

Thomas, P. (2011). Dasar - Dasar Keuangan. UNNES PRESS.

Uttari, I. A. S., \& Yadnya, I. P. (2018). KEBIJAKAN DIVIDEN DAN NILAI PERUSAHAAN ( Studi Pada Perusahaan Manufaktur yang Terdaftar di Bursa Efek Indonesia ). E-Jurnal Manajemen Unud, 7(6), 2942-2970. https:/ / doi.org/https:/ / doi.org/10.24843/EJMUNUD.2018.v7.i06.p4

Widyantari, N. L. P., \& Yadnya, I. P. (2017). Pengaruh Struktur Modal, Profitabilitas Dan Ukuran Perusahaan Terhadap Nilai Perusahaan Pada Perusahaan Food And Baverage Di Bursa Efek Indonesia. Jurnal Manajemen Udayana, 6(12), 6383-6409.

Wijaya, M. (2017). Analisis Faktor-Faktor Yang Mempengaruhi Kinerja Perusahaan Serta Dampaknya Terhadap Nilai Perusahaan. Media Riset Akuntansi, 4(2), Hal. 6792.

Yunita, I. G. P. A. O., \& Artini, L. G. S. (2019). Peran Struktur Modal Sebagai Mediator Antara Pertumbuhan Perusahaan Dan Nilai Perusahaaan. E-Jurnal Manajemen, 8(12), 7013-7032. 